\title{
Karakteristik Ibu Hamil dengan Covid-19 dan Luaran Persalinannya di Rumah Sakit Kasih Ibu Surakarta
}

\author{
Nabila Arnest Amorita ${ }^{1}$, Ira Syahriarti ${ }^{2}$ \\ 1,2Departemen Obstetri dan Ginekologi, Rumah Sakit Kasih Ibu Surakarta, \\ Jalan Slamet Riyadi 404, Surakarta, Indonesia, Telp. (0271) 714422 \\ Korespondensi: arnest.amorita@gmail.com
}

Submisi: 7 Februari 2021; Revisi:8 Maret 2021; Penerimaan: 15 Maret 2021

\begin{abstract}
Background: Kasih Ibu Hospital as one of the referral hospitals for COVID-19 in Surakarta City, Central Java, had treated 1333 confirmed cases of COVID-19, including among them obstetric patients with COVID-19. Pregnant women are considered to be more susceptible to COVID-19 infection than those who are not pregnant and it is feared that it will result in unfavorable conditions for both mother and fetus. Until now, research on pregnant women with COVID-19 in Indonesia is still very few and limited.

Objective: To provide an overview of the characteristics of maternal and neonatal outcomes at the Kasih Ibu Hospital Surakarta.

Method: Data were collected from medical records of pregnant women confirmed with COVID-19 who gave birth at the Kasih Ibu Hospital, Surakarta. Data was presented in the form of a distribution based on maternal age, parity, gestational age, complication of delivery, typical complaints of COVID-19 in mothers, birth weight of infant, infant APGAR score, and infant COVID-19 status.

Results and Discussion: A total of 62 pregnant women confirmed with COVID-19 gave birth at the Kasih Ibu Hospital Surakarta by sectio caesarean procedure. Of all pregnant women, most were asymptomatic and had mild symptoms, only $3.2 \%$ had moderate symptoms and no severe or critical symptoms were found. Out of 20 out of 62 babies born (32\%) confirmed with COVID-19. All babies were born with good APGAR score and 4 babies were found with low birth weight, one of whom also had hypospadias.
\end{abstract}

Conclusion: Further research is needed regarding the maternal-fetal transmission of COVID-19.

Keywords: COVID-19; neonates; pregnancy

\section{ABSTRAK}

Latar Belakang: Rumah Sakit Kasih Ibu sebagai salah satu rumah sakit rujukan COVID-19 di Kota Surakarta, Jawa Tengah, telah merawat 1333 kasus terkonfirmasi COVID-19, termasuk juga di antaranya pasien obstetri dengan COVID-19. Ibu hamil dianggap lebih rentan terinfeksi COVID-19 dan dikhawatirkan akan mengakibatkan keadaan yang kurang menguntungkan bagi ibu dan bayi. Hingga saat ini penelitian tentang ibu hamil dengan COVID-19 di Indonesia masih sangat sedikit dan terbatas.

Tujuan: Memberikan gambaran karakteristik ibu hamil dengan COVID-19 dan luaran persalinannya di Rumah Sakit Kasih Ibu Surakarta.

Metode: Penelusuran data rekam medis ibu hamil terkonfirmasi COVID-19 yang melakukan persalinan di Rumah Sakit Kasih Ibu Surakarta. Data disajikan dalam bentuk distribusi berdasarkan usia ibu, paritas, usia kehamilan, penyulit persalinan, keluhan khas COVID-19 pada ibu, berat lahir bayi, skor APGAR bayi, dan status COVID-19 bayi.

Hasil dan Pembahasan: Sebanyak 62 ibu hamil terkonfirmasi COVID-19 telah melakukan persalinan di Rumah Sakit Kasih Ibu Surakarta dan persalinan dilakukan dengan SC elektif. Dari keseluruhan ibu hamil, sebagian besar asimptomatik dan gejala ringan, hanya 3,2\% yang mengalami gejala sedang dan tidak ditemukan gejala berat maupun kritis. Luaran persalinan didapatkan 20 dari total 62 bayi yang lahir (32\%) terkonfirmasi COVID-19. Seluruh bayi lahir dengan skor APGAR baik dan ditemukan 4 bayi dengan berat badan lahir rendah yang salah satunya juga mengalami hipospadia.

Kesimpulan: Perlu dilakukan penelitian lebih lanjut mengenai transmisi COVID-19 pada ibu ke janinnya.

Kata Kunci: COVID-19; kehamilan; neonatus 


\section{PENDAHULUAN}

Sejak ditemukan pada Desember 2019 di Wuhan, China, severe acute respiratory syndrome coronavirus 2 (SARS-CoV-2) menyebabkan gangguan saluran pernapasan akut yang disebut dengan coronavirus disease 2019 (COVID-19) telah menjangkit sebagian besar populasi rentan di seluruh dunia dengan laju penularan yang begitu cepat hingga menimbulkan krisis kesehatan global. ${ }^{1,2}$ Pada Februari 2021, WHO telah mencatat sebanyak 103 juta kasus terkonfirmasi dengan 2,25 juta kematian yang disebabkan oleh COVID-19, dengan Indonesia sebagai salah satu penyumbang kasus aktif harian terbanyak ke- 5 di dunia dan total kasus konfirmasi terbanyak ke- 5 di Asia, yakni lebih dari 1,1 juta kasus. ${ }^{3}$ Jawa Tengah merupakan propinsi dengan jumlah kasus terbanyak ke-3 di Indonesia 126.000 kasus (11,6\% dari seluruh kasus di Indonesia). ${ }^{4}$ Rumah Sakit Kasih Ibu sebagai salah satu rumah sakit rujukan lini kedua penanggulangan pandemi COVID-19 di Kota Surakarta, Jawa Tengah, sampai tanggal 1 Februari 2021 telah merawat 1333 kasus terkonfirmasi COVID-19, termasuk juga di antaranya pasien obstetri dengan COVID-19.

Manifestasi klinis yang dapat ditemui pada kasus COVID-19 bervariasi dari gejala pernapasan berupa demam, batuk kering, sesak napas hingga manifestasi klinis lain yang lebih tidak khas seperti diare, limfopenia, dan hasil foto toraks yang menunjukkan adanya abnormalitas paruparu. Berdasarkan tingkat keparahannya, infeksi COVID-19 terbagi menjadi asimptomatik dan gejala ringan-sedang $(80 \%)$, gejala berat $(15 \%)$ dan kritis (5\%) yang bisa berupa pneumonia yang berprogresi menjadi acute respiratory distress syndrome (ARDS), syok septik, dan komplikasi sistemik lainnya yang membutuhkan ventilasi mekanik. ${ }^{5}$

Ibu hamil dan janinnya termasuk populasi yang berisiko tinggi terinfeksi COVID-19. Menurut data Perkumpulan Obstetri dan Ginekologi Indonesia (POGI) Jakarta, $13,7 \%$ ibu hamil lebih rentan terinfeksi COVID-19 daripada yang tidak hamil dan dikhawatirkan akan mengakibatkan keadaan yang kurang menguntungkan bagi ibu dan bayi, seperti terjadinya kelahiran preterm, preeklampsia, kelahiran dengan sectio cesarea hingga kematian perinatal. ${ }^{6}$ Perubahan fisiologis dan mekanis pada kehamilan menyebabkan peningkatan kerentanan terhadap infeksi secara umum, terutama bila mengenai sistem kardiorespirasi yang berisiko menyebabkan gagal napas pada ibu hamil. Ibu hamil juga mengalami perubahan fisiologis yang memicu perubahan respon imun dari respon Th1 ke arah dominasi Th2, yang mana berfungsi protektif terhadap fetus namun menyebabkan ibu lebih rentan terhadap paparan infeksi. ${ }^{7}$

Meskipun angka infeksi COVID-19 di Indonesia dan dunia meningkat secara signifikan selama setahun terakhir, penelitian tentang ibu hamil dengan penyakit ini masih sangat terbatas dan terus berkembang. Sampai saat ini juga masih belum jelas apakah infeksi COVID-19 dapat melewati rute transplasenta menuju bayi. Sebuah literatur yang dibuat di Cina, sebagai tempat dimana virus ini berasal, mencatat luaran 55 ibu hamil dan 46 neonatus tanpa adanya bukti transmisi vertikal dimana semua hasil swab bayi dinyatakan negatif dari COVID-19, sedangkan di literatur lain di Italia yang terbaru telah melaporkan kasus adanya 19 neonatus yang terkonfirmasi positif COVID-19 dari total 665 neonatus yang dilahirkan dari ibu yang terinfeksi COVID-19.8,9 Masih banyak informasi yang belum diketahui secara pasti mengenai luaran persalinan selama pandemi COVID-19, termasuk di antaranya kemungkinan transmisi vertikal dan kondisi bayi baru lahir yang terinfeksi COVID-19.

Konsensus yang baru saja dikeluarkan menyatakan bahwa tidak ada bukti yang kuat mengenai waktu persalinan, keamanan persalinan pervaginam, atau apakah persalinan dengan sectio cesarea (SC) dapat menghindari transmisi vertikal pada saat persalinan. Maka dari itu, metode dan waktu persalinan seharusnya didasarkan pada indikasi obstetri dan status infeksi ibu. Hal ini tentu saja menjadi tantangan bagi dokter ahli obstetri dan bidan dalam menolong persalinan mengingat risiko infeksi yang dihadapi ibu, bayi, maupun penolong. ${ }^{9}$

Berdasarkan hal tersebut, peneliti mengamati dan merangkum karakteristik ibu hamil dengan COVID-19 dan luaran persalinannya di Rumah Sakit Kasih Ibu yang menjadi lini kedua rujukan pasien obstetri dengan COVID-19 di Kota Surakarta. 


\section{TUJUAN}

Penelitian ini bertujuan memberikan gambaran karakteristik ibu hamil dengan COVID-19 dan luaran persalinannya di Rumah Sakit Kasih Ibu Surakarta. Diharapkan penelitian ini dapat menjadi dasar untuk pengamatan lebih lanjut terhadap faktor risiko transmisi vertikal COVID-19 dari ibu ke bayinya.

\section{METODE}

Peneliti melakukan penelusuran rekap data dan rekam medis ibu hamil yang terkonfirmasi COVID-19 dan melakukan persalinan di Rumah Sakit Kasih Ibu Surakarta. Pasien dinyatakan terkonfirmasi COVID-19 berdasarkan data hasil tes usap polymerase chain reactions (PCR) yang sampelnya diambil di Puskesmas pada usia kehamilan 37 minggu bagi yang terprogram maupun sesudah dirawat di rumah sakit untuk tes usap evaluasi. Data disajikan dalam bentuk distribusi berdasarkan usia ibu, paritas, usia kehamilan, penyulit persalinan, berat lahir bayi, skor APGAR bayi, dan status COVID-19 bayi. Usia kehamilan yang dimaksud adalah usia kandungan saat pasien terkonfirmasi COVID-19 berdasarkan hasil tes usap PCR. Data paritas dibagi menjadi 4 kategori; primigravida, sekundigravida, multigravida, dan grandemultigravida. Status COVID-19 bayi dinyatakan berdasarkan hasil tes usap PCR bayi baru lahir yang sampelnya diambil maksimal 24 jam setelah kelahiran di rumah sakit.

\section{HASIL DAN PEMBAHASAN}

Sejak awal ditunjuk sebagai rumah sakit rujukan lini kedua penanganan COVID-19 di Kota Surakarta hingga saat penelitian ini ditulis, Rumah Sakit Kasih Ibu telah melakukan persalinan pada sebanyak 62 ibu hamil terkonfirmasi COVID-19 pada bulan September 2020 hingga 3 Februari 2021. Sebaran kasus dapat dilihat di tabel 1 .
Tabel 1. Sebaran Data Ibu Hamil dan Luaran Persalinan

\begin{tabular}{|c|c|c|}
\hline Variabel & Jumlah & Persentase \\
\hline \multicolumn{3}{|l|}{ Usia Ibu } \\
\hline$<20$ & 0 & 0 \\
\hline $20-35$ & 56 & 90,3 \\
\hline$>35$ & 6 & 9,7 \\
\hline \multicolumn{3}{|l|}{ Paritas } \\
\hline Primigravida & 23 & 37,1 \\
\hline Sekundigravida & 19 & 30,65 \\
\hline Multigravida & 19 & 30,65 \\
\hline Grandemultigravida & 1 & 1,6 \\
\hline \multicolumn{3}{|l|}{ Usia Kehamilan } \\
\hline 37 & 7 & 11,3 \\
\hline 38 & 28 & 45,2 \\
\hline 39 & 21 & 33,9 \\
\hline 40 & 6 & 9,6 \\
\hline \multicolumn{3}{|l|}{ Gejala COVID-19 } \\
\hline Asimptomatik & 24 & 38,7 \\
\hline Batuk & 25 & 40,3 \\
\hline Demam & 3 & 4,8 \\
\hline Anosmia & 8 & 12,9 \\
\hline Sesak napas & 2 & 3,2 \\
\hline \multicolumn{3}{|l|}{ Indikasi SC } \\
\hline KPD & 18 & 29,0 \\
\hline PEB & 2 & 3,2 \\
\hline Riwayat SC & 5 & 8,1 \\
\hline Presbo & 1 & 1,6 \\
\hline COVID-19 & 36 & 59,1 \\
\hline \multicolumn{3}{|l|}{ Jenis Kelamin Bayi } \\
\hline Laki-laki & 32 & 51,6 \\
\hline Perempuan & 30 & 48,4 \\
\hline \multicolumn{3}{|l|}{ Berat Lahir Bayi } \\
\hline$<2500$ & 4 & 6,5 \\
\hline $2500-4000$ & 58 & 93,5 \\
\hline$>4000$ & 0 & 0 \\
\hline \multicolumn{3}{|l|}{ Skor APGAR Bayi } \\
\hline$<8$ & 0 & 0 \\
\hline $8-9$ & 47 & 75,8 \\
\hline $9-10$ & 15 & 24,2 \\
\hline \multicolumn{3}{|l|}{ Hasil tes usap PCR Bayi } \\
\hline Positif & 20 & 32,3 \\
\hline Negatif & 42 & 67,7 \\
\hline
\end{tabular}

Tabel 2. Angka Kejadian Kasus Bayi Positif COVID-19 2020-2021

\begin{tabular}{lcc}
\multicolumn{1}{c}{ Bulan } & Jumlah & Persentase \\
November 2020 & 1 & 5 \\
Desember 2020 & 1 & 5 \\
Januari 2021 & 18 & 90 \\
\hline
\end{tabular}


Seluruh persalinan dilakukan dengan SC elektif; 29\% dengan indikasi ketuban pecah dini, 3,2\% karena preeklampsia berat, $8 \%$ karena riwayat SC sebelumnya, 1,61\% karena presentasi bokong dan sisanya sebanyak 59,6\% karena indikasi COVID-19 itu sendiri. Studi yang dilakukan oleh Valente et al. melaporkan tidak ditemukan adanya risiko transmisi vertikal apabila bayi dilahirkan pervaginam, sehingga persalinan pervaginam tidak dikontraindikasikan. ${ }^{10}$ Meskipun begitu, pada sebagian besar kasus COVID-19 di luar negeri yang dinyatakan oleh beberapa peneliti, prosedur SC adalah yang paling sering dilakukan untuk menangani kasus COVID-19, dengan pertimbangan perburukan kondisi maternal, sulitnya melakukan ventilasi mekanis pada uterus gravid dan fetal compromise. ${ }^{1}$

Rerata usia ibu hamil dengan COVID-19 yang melakukan persalinan di Rumah Sakit Kasih Ibu Surakarta yaitu 28,1 tahun dengan yang termuda berusia 20 tahun dan yg tertua 42 tahun. Sebanyak $90,3 \%$ dari total jumlah populasi berusia antara 2035 tahun, artinya sebagian besar ibu hamil yang dirawat memiliki risiko yang relatif rendah untuk terjadinya komplikasi persalinan bila hanya dilihat dari variabel usia. Mayoritas dari ibu hamil yang berusia muda menyebabkan populasi primigravida adalah yang terbanyak dibanding yang lain, yakni menempati sebanyak $37,1 \%$ dari keseluruhan, diikuti dengan 30,65\% masing-masing sekundigravida dan multigravida. Meskipun jarang, namun ditemukan juga satu kasus grandemultigravida yakni gravida ketujuh. Belum diketahui apakah ada kaitan antara paritas dengan kerentanan ibu hamil terhadap infeksi COVID-19.

Usia kehamilan saat pasien terdiagnosis COVID-19 seluruhnya adalah ketika sudah aterm, yakni berkisar antara minggu 37-40 kehamilan, dengan rerata usia kehamilan 38,4 minggu. Hal ini dikarenakan Puskesmas telah melakukan skrining pasien materna yang telah menginjak usia aterm untuk melakukan pemeriksaan tes usap PCR, sehingga pasien yang terkonfirmasi positif COVID-19 segera dirujuk ke fasilitas kesehatan sekunder yang dapat melakukan prosedur SC elektif di ruang operasi bertekanan negatif untuk mengurangi paparan terhadap tenaga kesehatan yang menolong persalinan.
Sebagian besar ibu hamil yang dirujuk untuk melakukan persalinan di Rumah Sakit Kasih Ibu Surakarta adalah hanya berdasarkan hasil tes usap PCR positif COVID-19, yaitu sebanyak $38,7 \%$ tidak mengeluhkan gejala apapun (asimptomatik). Sisanya, sebanyak 40,3\% mengeluhkan gejala khas COVID-19 yang ringan berupa batuk, 12,9\% anosmia, 4,8\% demam, dan 3,2\% mengeluhkan keluhan sedang berupa sesak napas. Tidak ditemukan adanya kasus berat atau kritis dan tidak pula ditemukan kematian pada ibu hamil dengan COVID-19 pada penelitian ini. Hal ini selaras dengan penelitian yang dilakukan Wong et al yang membandingkan case fatality rate antara COVID-19, SARS dan MERS berturut-turut yakni $0 \%, 18 \%$ dan $25 \%$. Pada SARS dan MERS, kegagalan respiratori progresif dan sepsis berat sering ditemukan pada ibu hamil. ${ }^{11,12}$

Luaran persalinan yang menjadi fokus penelitian ini adalah keadaan bayi. Bayi yang lahir dari ibu terkonfirmasi COVID-19 pada penelitian ini berjumlah 62 bayi dan seluruhnya lahir hidup. Rerata berat bayi lahir adalah 3018,1 gram, dengan berat terendah 1900 gram dan tertinggi 3900 gram. Sebanyak 4 bayi lahir dengan kondisi berat badan lahir rendah, yakni kurang dari 2500 gram. Di antara 4 bayi tersebut, salah satunya lahir dengan kelainan hipospadia. Skor APGAR yang dilaporkan keseluruhannya baik dengan skor 8-9 di menit pertama dan 9-10 di menit kelima. Berdasarkan data, belum bisa dibuktikan apakah ada hubungan antara infeksi COVID-19 pada ibu hamil dengan berat lahir maupun kelainan yang dialami bayi. Dalam literatur yang ditulis Chen et al., pada studi yang dilakukan pada 9 ibu hamil, hanya satu bayi yang memiliki berat lahir rendah dan itu disebabkan karena ibu memiliki faktor penyulit preeklampsia dan tidak berkaitan dengan infeksi COVID-19. ${ }^{13}$ Meskipun pada kasus ini belum ditemukan adanya data penyulit seperti preeklampsia atau anemia, bisa jadi ada faktor lain yang menyebabkan bayi dengan berat lahir rendah seperti postur ibu dan gizi, sehingga untuk saat ini belum bisa disimpulkan apakah berkaitan dengan COVID-19.

Fenomena lain yang ditemukan yakni didapatkan sejumlah 20 dari total 62 bayi terkonfirmasi positif COVID-19 dari hasil tes usap PCR, yakni 32,3\% dari total keseluruhan populasi. Meskipun begitu, tidak 
ada laporan adanya gejala maupun komplikasi yang dialami bayi setelah diketahui positif terinfeksi COVID-19. Belum diketahui secara pasti apakah bayi mendapatkan infeksi melalui transmisi vertikal transplasental ataupun horizontal saat peripartum. Mengacu pada tabel 2, angka kejadiannya meningkat secara signifikan seiring waktu, karena tercatat pada tahun 2020 hanya 2 bayi yang terkonfirmasi positif sedangkan pada bulan Januari hingga tanggal 3 Februari 2021 didapatkan 18 kasus sekaligus. Menurut studi retrospektif yang dilakukan oleh Chen et al., setelah melakukan pengambilan sampel cairan amnion, darah umbilikal, air susu ibu, dan tes usap bayi baru lahir dari ibu yang terkonfirmasi COVID-19, tidak ditemukan jejak virus SARS-CoV-2, sehingga bisa disimpulkan bahwa tidak terjadi transmisi transplasental pada COVID-19. ${ }^{14,15}$ Di sisi lain, studi yang dilakukan Parazzini et al. melaporkan adanya 2 bayi baru lahir yang terkonfirmasi positif COVID-19 dari 13 studi kasus yang menyimpulkan bahwa ada kemungkinan terjadinya transmisi vertikal maupun peripartum namun belum dapat diketahui penyebab pastinya. ${ }^{9}$ Tentu saja hal ini masih perlu diteliti lebih lanjut mengingat terjadinya peningkatan kasus bayi positif COVID-19 yang cukup signifikan di RS Kasih Ibu Surakarta dalam sebulan terakhir.

Kekurangan dari studi ini adalah kurangnya jumlah referensi penelitian mengenai ibu hamil dengan COVID-19 dan luaran persalinannya. Meskipun beberapa laporan kasus dapat ditelaah, jumlah sampel dari masing-masing penelitian masih terlalu sedikit dengan keadaan yang bervariasi. Sedangkan kelebihan dari penelitian ini adalah dapat mengumpulkan sejumlah 62 subjek yang kesemuanya telah dinyatakan positif COVID-19 berdasarkan hasil PCR dengan populasi yang cukup homogen. Harapan peneliti ke depan dengan jumlah kasus COVID-19 yang telah berjumlah jutaan, seharusnya dapat dilakukan penelitian lebih lanjut terutama pada kasus ibu hamil dimana masih banyak informasi yang belum diketahui

\section{KESIMPULAN DAN SARAN}

Sebanyak 62 ibu hamil terkonfirmasi COVID-19 telah melakukan persalinan di Rumah Sakit Kasih Ibu Surakarta sejak September 2020 hingga awal Februari 2021. Seluruh persalinan dilakukan dengan SC elektif sesuai dengan kesepakatan standar prosedur persalinan dengan COVID-19 untuk mengurangi kemungkinan terjadinya gagal napas pada ibu dan paparan infeksi pada penolong persalinan. Dari keseluruhan ibu hamil, sebagian besar asimptomatik dan gejala ringan, hanya $3,2 \%$ yang mengalami gejala sedang dan tidak ditemukan gejala berat maupun kritis. Luaran persalinan yang menjadi perhatian adalah keadaan dan status COVID-19 bayi, dimana didapatkan 20 dari total 62 bayi yang lahir (32\%) terkonfirmasi COVID-19. Seluruh bayi lahir dalam keadaan bugar dengan rerata skor APGAR dan ditemukan 4 bayi dengan berat badan lahir rendah yang salah satunya juga mengalami hipospadia. Belum diketahui secara pasti cara transmisi vertikal dari ibu ke janinnya karena penelitian tentang ibu hamil dan COVID-19 masih sangat baru dan terbatas. Sebagai populasi yang rentan, perlu dilakukan sosialisasi dan upaya preventif yang lebih ketat untuk mencegah penularan COVID-19 pada ibu hamil, baik dari regulasi pemerintah maupun dari masing-masing individu.

\section{DAFTAR PUSTAKA}

1. Dashraath $P$ et al. 2020. Coronavirus disease 2019 (COVID-19) pandemic and pregnancy. American journal of obstetrics and gynecology, 222(6), 521-531.

2. Cuñarro-López $Y$ et al, 2021. The Profile of the Obstetric Patients with SARS-CoV-2 Infection According to Country of Origin of the Publication: A Systematic Review of the Literature. Journal of clinical medicine, 10(2), 360.

3. https://covid19.who.int/table, diakses 3 Februari 2021.

4. https://covid19.go.id/peta-sebaran, diakses 3 Februari 2021.

5. Chen H., et al, 2020. Clinical characteristics and intrauterine vertical transmission potential of COVID-19 infection in nine pregnant women: a retrospective review of medical records. Lancet (London, England), 395(10226), 809-815. https:// doi.org/10.1016/S0140-6736(20)30360-3.

6. Rohmah, M K., Nurdianto, A R. 2020. Corona Virus Disease 2019 (COVID-19) pada Ibu Hamil dan Bayi: Sebuah Tinjauan Literatur. Medica Hospitalia, 7(1). 
7. Nurdianto AR, Aryati, Mohammad GS, Mufasirin, 2019. Downregulates of icam1 expression in myometrium from pregnant rattus norvegicus infected with tachyzoite of toxoplasma gondii with hyperbaric oxygen therapy. Hang Tuah Medical Journal. 17: 77-83.

8. Yan J, Guo J, Fan C, Juan J, Yu X, et al, 2020. Coronavirus disease 2019 in pregnant women: a report based on 116 cases. Am J Obstet Gynecol. 2020; 223: 111.e1-14.

9. Parazzini $F$ et al, 2020. Delivery in pregnant women infected with SARS-CoV-2: A fast review. International journal of gynaecology and obstetrics: the official organ of the International Federation of Gynaecology and Obstetrics, 150(1), 41-46. https://doi.org/10.1002/ijgo.13166

10. Polónia-Valente, R., Moucho, M., Tavares, M., Vilan, A., Montenegro, N., \& Rodrigues, T. (2020). Vaginal delivery in a woman infected with SARSCoV-2 - The first case reported in Portugal. European journal of obstetrics, gynecology, and reproductive biology, 250, 253-254.
11. Wong S.F., Chow K.M., de Swiet M. 2003. Severe acute respiratory syndrome and pregnancy. BJOG. 2003; 110: 641-642.

12. Zhang I, Jiang Y, Wei M, et al. 2020. [Analysis of pregnancy outcomes of pregnant women during the epidemic of new coronavirus pneumonia in Hubei]. Zhonghua Fu Chan Ke Za Zhi. 55(0):E009

13. Liu H et al. 2020. Clinical and CT imaging features of the COVID-19 pneumonia: focus on pregnant women and children. J Infect. doi: 10.1016/j. jinf.2020.03.007 [Epub ahead of print].

14. Chen D., et al, 2020. Expert consensus for managing pregnant women and neonates born to mothers with suspected or confirmed novel coronavirus (COVID-19) infection. Int J Gynecol Obstet. [Epub ahead of print].

15. Chen L., et al. 2020. Clinical Characteristics of Pregnant Women with Covid-19 in Wuhan, China. The New England journal of medicine, 382(25), e100. 